IARGE

\section{Laboratoire}

de Recherche

en Gestion

\& Economie

W

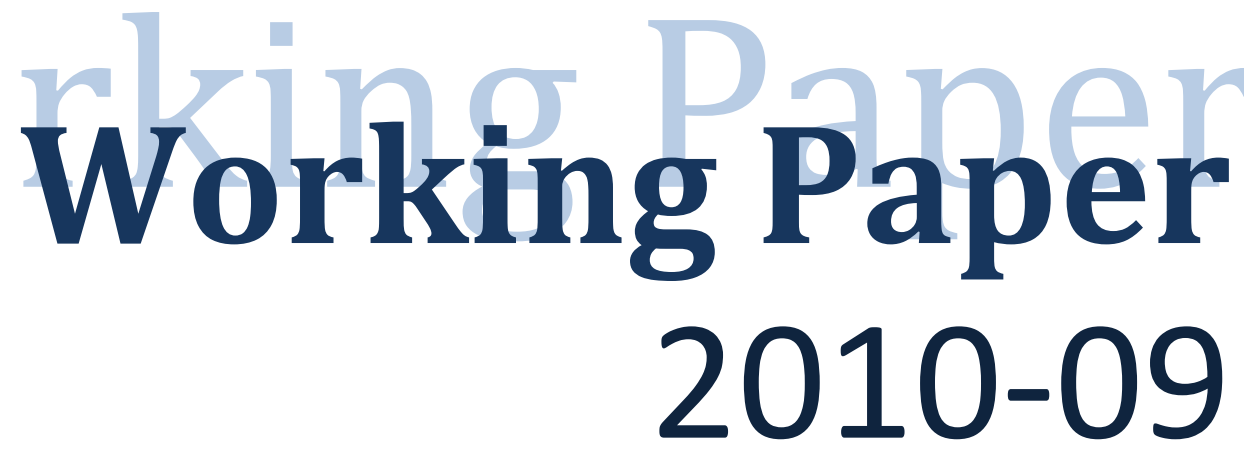

Market Power in the Russian Banking Industry

Zuzana Fungáčová, Laura Solanko, Laurent Weill

June 2010 


\title{
Market Power in the Russian Banking Industry
}

\author{
Zuzana Fungáčová \\ BOFIT, Bank of Finland \\ Laura Solanko ${ }^{\#}$ \\ BOFIT, Bank of Finland \\ Laurent Weill* \\ Université de Strasbourg and EM Strasbourg Business School
}

\begin{abstract}
$\underline{\text { Abstract }}$
The aim of this paper is to analyze bank competition in Russia by measuring the market power of Russian banks and its determinants over the period 2001-2007 with the Lerner index. Earlier studies on bank competition have focused on developed countries whereas this paper contributes to the analysis of bank competition in emerging markets. We find that bank competition has only slightly improved during the period studied. The mean Lerner index for Russian banks is of the same magnitude as those observed in developed countries, which suggests that the Russian banking industry is not plagued by weak competition. Furthermore, we find no greater market power for state-controlled banks nor less market power for foreign-owned banks. We would consequently qualify the procompetitive role of foreign bank entry and privatization. Finally, our analysis of the determinants of market power enables the identification of several factors that influence competition, including market concentration and risk as well as the nonlinear influence of size.
\end{abstract}

JEL Codes : G21, P34.

Keywords : market power, bank competition, Russia.

\footnotetext{
\# Bank of Finland, Institute for Economies in Transition (BOFIT), PO Box 160, FI-00101 Helsinki. E-mail: zuzana.fungacova@bof.fi

${ }^{\#}$ Bank of Finland, Institute for Economies in Transition (BOFIT), PO Box 160, FI-00101 Helsinki. E-mail: laura.solanko@bof.fi

* Institut d'Etudes Politiques, Université de Strasbourg, 47 avenue de la Forêt Noire, 67082 Strasbourg

Cedex. Phone : 33-3-88-41-77-54. Fax : 33-3-88-41-77-78. E-mail : laurent.weill@unistra.fr
} 


\section{Introduction}

In the wake of major structural changes in banking industries around the globe, the impact of bank competition on economic growth has generated increasing interest in the literature of recent years. Since banks play a key role in the financing of the economy, changes in bank competition are supposed to exert an impact on access to bank finance in the form of lower loan rates or relaxing of financing constraints (Cetorelli and Gambera, 2001; Carbo-Valverde, Rodriguez-Fernandez and Udell, 2009). Such developments would suggest a positive impact of bank competition on economic growth (Claessens and Laeven, 2005).

Bank competition is even more important for economic growth in emerging countries. First, these countries are characterized by low ratios of credit to GDP, which may be a result of the financing obstacles created by subdued banking competition. Second, bank lending is the leading source of external finance in these countries, owing notably to underdeveloped capital markets. In spite of this, earlier studies investigating the level and the determinants of bank competition focus instead on developed countries (e.g. Fernandez de Guevara, Maudos and Perez, 2005).

Russia is a very interesting example of such an emerging market. Bank lending is stunningly low, with a ratio of domestic credit to GDP of $25.7 \%$ in 2005, compared with a world average of 55.8\% (EBRD, 2006). At the same time, bank lending represents the largest source of external finance for companies ${ }^{1}$. This picture has not changed despite impressive economic and banking-sector growth in recent years, including a doubling of the ratio of banking sector assets to GDP.

Our aim in this paper is to analyze bank competition in Russia in the recent years by measuring the market power of Russian banks over the period 2001-2007. We utilize a rich panel dataset from the financial information agency Interfax and the Central Bank of Russia, which provides quarterly data for all Russian banks. In line with recent studies on bank competition (Fernandez de Guevara, Maudos and Perez, 2005; Solis and Maudos, 2008; Berger, Klapper and Turk-Ariss, 2009; Carbo-Valverde et al., 2009), bank

\footnotetext{
${ }^{1}$ The 2009 OECD report on Russia also stresses the importance of bank lending by mentioning that "Russia has seen the rapid evolution of securities markets and other non-bank financial activity, especially in the past 8 years or so, but banking still accounts for almost all financial intermediation” (OECD, 2009, p.122)
} 
competition is measured by the Lerner index. This measure of market power directly infers a bank's conduct and then informs on the actual behavior of the bank.

First, we measure the level and the evolution of the market power of Russian banks during the period of study. We assess the level of market power of banks in Russia and compare it with other countries. We also investigate whether strong economic growth influenced banking competition in recent years.

Second, we investigate whether market power depends on ownership. Russian banking is characterized by the coexistence of three different types of banks: statecontrolled banks, domestic private banks, foreign-owned banks. We analyze whether the

privatization of state-controlled banks or relaxing of foreign bank entry contribute to reducing market power in the Russian banking industry.

Third, we analyze the determinants of market power for Russian banks. This is done to provide relevant insights for economic policy, by identifying factors which can be influenced so as to enhance bank competition. Furthermore, this analysis allows us to examine the extent to which these determinants are similar to those observed in other countries. Indeed, earlier studies on determinants of banks' market power have all looked at developed countries (Fernandez de Guevara, Maudos and Perez, 2005; Fernandez de Guevara and Maudos, 2007). Therefore, this identification of the determinants of banks' market power is a significant contribution to the analysis of bank competition in emerging countries.

The rest of the article is structured as follows. Section 2 describes the Russian banking industry. Section 3 sets out the methodology and data. Section 4 presents the results, and Section 5 concludes.

\section{Russian banking sector, 1998-2008}

In stark contrast to the volatile 1990s and the financial and economic crisis of 1998, the last ten years have witnessed a Russian banking sector starting to resemble banking sectors in many other emerging economies. Russian banks by and large take in retail deposits, provide credits to both households and enterprises, engage in fairly 
standard operations in capital markets, and issue bonds; some even participate in international loan syndications.

The Russian ruble has been freely convertible since July 2006, and there are no restrictions on the capital account. Payments do flow across Russia's eleven time zones fairly reliably, several foreign banks have found their way into the top-10 banks, and even bank cards are in common use in the big cities. On the surface therefore, Russia's banking sector looks like that of a typical emerging economy. Deeper investigation however reveals a number of structural features uncommon for other European emerging economies.

The main difference is that no major bank privatization has ever occurred in Russia on the scale that was seen in Central European countries. The state has retained control over some of the Soviet-era sectoral banks, notably the major savings bank Sberbank and foreign-trade banks VTB-Vnestorgbank and VEB-Vnesekonbank. The large state-controlled banks have been significant players in the market throughout the post-Soviet period.

The corollary of this is that the private banks are mostly de novo banks, established in the early 1990s. Russia still has a very large number of private banks, most of them miniscule. Many of them are believed to be pocket-banks of an industrial group and to have little if any exposure to the interbank markets. There were more than 1300 banks operating in Russia in 2000. This number has decreased significantly over the last ten years even though the banking sector as a whole has grown substantially (see Table 1).

Due to the sheer size of the country, Russia's banking system entails wide regional variation. Roughly half of the banks are registered in the capital, Moscow City, and the other half are headquartered in the rest of Russia's 86 regions. Only the larger banks have regional networks to speak of, and the majority of Russian banks do not conduct major operations outside their home regions. Out of the 1100 banks operating in 2008, only less than 300 have branch offices in other regions (CBR). Despite the impressive number of banks, there is wide regional variation in availability of banking services. Some of the remote regions in Russia are being served only by the state savings bank, Sberbank, and a handful of tiny private banks. In regions with larger cities, 
however, market concentration can be very low. The robust growth in the banking industry over the last decade has however clearly widened the scope of banking services available also outside Moscow. Berkowitz and DeJong (2008) argue that the emergence of bank credit has indeed been an important engine for real income growth across Russian regions since 2000.

The financial crisis in 1998 led to an increase in state's share in the banking sector, due to some bank takeovers and to deposit flight to state-controlled banks, understood to have implicit state guarantees. The crisis, however, also initiated a number of financial sector reforms that particularly favored private banks. The single most important reform was the introduction of a deposit insurance scheme in 2004, which was hoped to level the playing field between state-controlled and private banks. ${ }^{2}$ The state also, by 2004, withdrew its minority shareholdings in many medium and small-scale private banks. The plans to partly privatize the county's top banks, Sberbank and VTB, ended in large IPOs in 2007 that resulted in $40 \%$ and 23\% private shareholdings respectively in the two banks. No further privatization of the large state-owned banks is planned.

The reforms have clearly improved the legal environment, but they have not reduced the share of state-controlled banks in the Russian banking industry. According to Vernikov (2009), the share of the five largest state-related banking groups (Sberbank, VTB Group, Gazprombank Group, Rosselkhozbank, and Bank Moskvy) in total banking sector assets increased from 35\% in 2001 to 49\% in 2009. The current financial crisis has further increased the state's share in the sector. Vernikov (2009) estimates the share of predominantly state-owned banks in total banking sector assets at 56\% in July 2009.

Foreign bank penetration in Russia has been modest, albeit on the increase. There are no binding legal barriers to foreign bank entry, but the low foreign bank penetration can be partly explained by memories of the 1998 crisis when many foreign investors incurred huge losses. Moreover, the legal and regulatory environment in Russia is only slowly beginning to resemble that of many other transition countries. Foreign-owned banks are however becoming increasingly important. The number of banks with foreign

\footnotetext{
${ }^{2}$ For the effects of the introduction of the deposit insurance scheme and other reform packages see e.g. OECD (2009) and Berglöf and Lehmann (2009).
} 
ownership has increased from 174 in 2000 to 228 at the end of June $2009^{3}$. In early 2008 two of the top-10 banks in Russia were foreign-owned. The share of foreign-owned banks in total assets of Russian banking sector reached $17 \%$ in 2008.

In contrast to other emerging economies with similar income levels, the level of financial intermediation by banks is very low in Russia. However, the growth of the banking sector has been impressive since 2001. Since then, bank credit flows to the private sector have increased by more than 20 percent of GDP, reaching $36 \%$ at the end of 2007 (CBR). The spectacular growth rates were a product of an improving macroeconomic environment, higher income levels, availability of cheap foreign funding and domestic institutional reforms.

\section{Methodology}

\section{III.1 Lerner index}

Empirical research provides some tools for measuring bank competition. These can be broken down into the traditional Industrial Organization (IO) and new empirical IO approaches. The traditional IO approach proposes tests of market structure to assess bank competition based on the Structure Conduct Performance (SCP) model. The SCP hypothesis argues that greater concentration causes less competitive bank conduct and leads to higher bank profitability. According to this, competition can be measured by concentration indices such as market share of the largest banks or the Herfindahl index.

The new empirical IO approach provides non-structural tests to circumvent the problems connected to inferring competition from indirect proxies such as market structure or market shares under the traditional IO approach. In comparison, nonstructural measures measure banks' conduct directly using micro-level bank data.

Following the new empirical IO approach, we measure bank competition by the Lerner index, which is based on individual bank-level data. The Lerner index has been widely used in recent studies on bank competition and market power (e.g. Solis and

\footnotetext{
${ }^{3}$ Of 228 banks with foreign ownership, there were 106 with majority foreign ownership (i.e. more than $50 \%)$.
} 
Maudos, 2008, Carbo-Valverde et al., 2009). The Lerner index is defined as the difference between a bank's price and the marginal cost, divided by the price. The index values range from a maximum of 1 to a minimum of zero, with higher numbers indicating greater market power and hence less competition. The Lerner index in fact represents the extent to which a particular bank has market power to set its price above marginal cost. A zero value indicates perfect competition and no monopoly power.

The price is computed by estimating the average price of bank production (proxied by total assets) as the ratio of total revenue to total assets, following Fernandez de Guevara, Maudos and Perez (2005), Carbo-Valverde et al. (2009), and others. The marginal cost is estimated on the basis of a translog cost function with one output (total assets) and three input prices (price of labor, price of physical capital, and price of borrowed funds). Symmetry and linear homogeneity restrictions in input prices are imposed. The cost function is specified as

$$
\ln T C=\alpha_{0}+\alpha_{1} \ln y+\frac{1}{2} \alpha_{2}(\ln y)^{2}+\sum_{j=1}^{3} \beta_{j} \ln w_{j}+\sum_{j=1}^{3} \sum_{k=1}^{3} \beta_{j k} \ln w_{j} \ln w_{k}+\sum_{j=1}^{3} \gamma_{j} \ln y \ln w_{j}+\varepsilon
$$

where TC denotes total costs, $y$ total assets, $w_{1}$ the price of labor (ratio of personnel expenses to total assets) ${ }^{4}, w_{2}$ the price of physical capital (ratio of other non-interest expenses to fixed assets), $w_{3}$ the price of borrowed funds (ratio of interest paid to total funding). Total costs are the sum of personnel expenses, other non-interest expenses and interest paid. The indices for each bank and time have been dropped from the presentation for the sake of simplicity. The estimated coefficients of the cost function are then used to compute the marginal cost (MC):

$$
M C=\frac{T C}{y}\left(\alpha_{1}+\alpha_{2} \ln y+\sum_{j=1}^{3} \gamma_{j} \ln w_{j}\right)
$$

Once marginal cost is estimated and the price of output computed we can calculate the Lerner index for each bank and obtain a direct measure of bank competition.

\footnotetext{
${ }^{4}$ As our database does not provide information on the number of employees, we use this proxy variable for the price of labor, following Fernandez de Guevara, Maudos and Perez (2007) and Karas, Schoors and Weill (2010) among others.
} 


\section{III.2 Data and variables}

We use quarterly bank-level data from the financial information agency Interfax. Our sample is composed of observations from the first quarter of 2001 to the first quarter of 2007. To ensure that a bank carries out lending activities, we keep only banks with more than $5 \%$ of loans in total assets. Our final sample consists of over 24,000 bank quarter observations, which are available for the estimations. The data on bank foreign ownership is from the Central Bank of Russia (CBR). We define a bank to be foreignowned if the foreign ownership share in its assets exceeds 50\%. State-controlled banks are defined using the list provided in Vernikov (2007). Information on bank branches by regions is collected from the CBR website. Regional data are from Rosstat and the investor risk rating from the Russian rating agency ExpertRA ${ }^{5}$.

In the estimations, we analyze the determinants of the market power of Russian banks. To do so, we perform regressions of the Lerner index measuring market power on a set of variables. The selection of variables is based on two former studies on the determinants of market power: Fernandez de Guevara, Maudos and Perez (2005) (hereafter FMP), Fernandez de Guevara and Maudos (2007) (hereafter FM). Both of these studies investigate the determinants of banks' market power by computing Lerner indices, but they differ in their geographical scope. While FM (2007) focus on Spanish banks, FMP (2005) consider the five largest EU banking markets (France, Germany, Italy, Spain, the UK). Previous studies point out four key determinants of market power: concentration, size, elasticity of demand, and risk.

Herfindahl Index, as used to measure concentration, is defined as the Herfindahl index for assets computed at the regional level. Taking into account the size of Russian territory and great regional variability, the regional market is the relevant market for evaluating competition. We use distribution of branch offices as a proxy for banking output by region for calculating the Herfindahl index for a given region. The Herfindahl index for a bank thus measures the concentration of the markets in which it operates, using as weights the distribution of its branch networks in the regions. This variable is useful for checking whether a positive link exists between concentration and market power. The existence of such a link would be a strong argument, based on a need for

\footnotetext{
${ }^{5}$ Available at http://www.raexpert.ru/ratings/regions/.
} 
greater competition, against the consolidation of the Russian banking industry. While also using the Herfindahl index to measure concentration, FMP (2005) and FM (2007) interestingly find no significant coefficient for this variable.

We use the logarithm of total assets (Log(Assets)) to measure size. We also include the squared term $\left(\log \left(\right.\right.$ Assets $\left.^{2}\right)$ in the estimations to consider possible nonlinearity in the relationship between size and market power. There are several reasons for including this variable. First, as there have been many bank failures in Russia in recent years, being "too big to fail" can play a role by affording an advantage to large banks in attracting depositors, which could lead to wider margins. Second, economies of scale may exist, allowing the largest banks to benefit from lower costs. Third, existence of a relationship between size and market power would also contribute to the debate on consolidation in the Russian banking industry. A positive link would argue against a pro-merger policy for competitive reasons.

Loans to Industrial Production is calculated as a weighted average of the loans-toindustrial-production ratios of regions in which a given bank has operations. Similar to the case of concentration, we use weights based on the distribution of branch offices in regions. The loans-to-industrial-production ratio is used to proxy the elasticity of demand, following FM (2007) who use the ratio of loans to GDP at regional level for a similar purpose. The theory stresses that greater elasticity of demand through a lower value of this ratio, i.e. lower dependence on bank financing, results in less market power for banks. A positive relationship is thus expected between this ratio and market power.

Further, we account for the ratio of nonperforming loans to total loans to measure risk (Nonperforming Loans). This ratio is a standard measure of risk in the banking literature (e.g. Berger and DeYoung, 1997). It is used in the estimations since a higher nonperforming loans ratio is expected to reduce market power because of the losses involved. Furthermore, greater risk could divert depositors from the bank and hence increase the bank's costs of attracting clients. Both FMP (2005) and FM (2007) use the ratio of loan loss provisions to total loans. They stress that the nonperforming loans ratio would be a better measure of risk, but it cannot be used, for data availability reasons.

Next to the four key determinants, we add some variables of particular interest for Russian banks. We add dummy variables for foreign ownership (Foreign Ownership) and 
state ownership (State Ownership), in accordance with the potential role of ownership. We show that there are differences in market power between different ownership categories, which evolve over time; hence the link between these ownership forms and market power is ambiguous over the period. Furthermore, we include a variable for investor risk, which includes legal, economic, financial, social, criminal, ecological and administrative components (Investor Risk). Indeed a major concern in Russia is the weak institutional environment, which results in a notably high level of corruption by international standards (Weill, 2008). Studies have however shown the existence of strong differences in institutional environment among Russian regions, so the potential impact of investor risk should be considered. Finally, we control for the business cycle by including regional growth of industrial production (Industrial Growth).

Dummy variables for each quarter and each year are also included in the estimations, to control for seasonal and yearly effects.

Descriptive statistics for all variables are reported in Table 2.

\section{Results}

This section provides the analysis of market power of Russian banks. We begin by providing information on the level and evolution of the Lerner index for Russian banks. We then investigate whether these indices differ by bank ownership. Next we analyze the determinants of market power of Russian banks.

\section{IV.1 Market power of Russian banks}

We present the estimates of market power for Russian banks for each year in Table 3. We observe that the average Lerner index for the period is $21.4 \%$. Therefore, market power of banks in Russia is very similar to that observed in developed countries. For instance, Fernandez de Guevara and Maudos (2007) find yearly mean Lerner indices between $16.9 \%$ and $24.9 \%$ for Spanish banks, while Carbo-Valverde and al. (2009) observe mean Lerner indices at the country level ranging from $11 \%$ to $22 \%$ for $\mathrm{EU}$ countries, with an EU mean of $16 \%{ }^{6}$.

\footnotetext{
${ }^{6}$ It is necessary to point out that the data we use are based on RAS, which differ from IFRS data.
} 
In dynamic terms, the evolution of the Lerner index shows a relatively stable level of bank competition over the period with yearly means ranging from $20.1 \%$ to $21.4 \%$ and a reduction of the variability of Lerner indices over time. We nonetheless observe a slight decrease over the period, from $21.4 \%$ in 2001 to $20.4 \%$ in 2007 , which is statistically significant.

The analysis of the mean Lerner index for the Russian banking industry is of utmost interest to investigate average bank behavior. However, the appraisal of the macroeconomic effects of changes in bank competition notably through changes in loan rates needs to consider differently banks according to their market share. As mentioned above, there are huge differences in size among Russian banks and, notably, a market share of about 30\% for the largest bank (Sberbank). Therefore, we also measure the mean Lerner index weighted by market shares of banks in total banking sector assets. These figures are also presented in Table 3.

We point out two striking findings. On the one hand, the trend for the mean weighted Lerner index is similar to the one observed with the standard mean Lerner index. We still observe a slight reduction of the market power, supporting the view of moderately enhanced bank competition. On the other hand, the mean weighted Lerner index has lower values than the standard Lerner index, which supports the view of a level of bank competition in Russia similar to that in other countries.

As a consequence, our main finding is that, in spite of the major changes in Russia in recent years, including strong economic growth and banking reforms (e.g. the deposit insurance scheme), bank competition has only slightly improved in recent years. One can notably wonder why the changes in the banking industry, such as the increasing market share for foreign banks, have not enhanced bank competition. To this end, it is interesting to investigate market power by ownership type.

\section{IV.2 Market power by ownership type}

As mentioned above, the Russian banking industry is characterized by a persistently large market share for state-controlled banks and a relatively small market share of foreign-owned banks, in comparison with the other transition countries. Thus, it is interesting to investigate how these characteristics influence banks' behavior in Russia. 
We investigate whether foreign-owned, state-controlled and domestic private banks differ in market power and thus aim to uncover whether the ownership structure of the Russian banking industry affects bank competition. Table 4 presents the mean Lerner indices for each category of banks and for each year. Several conclusions emerge.

First, the ranking of categories in terms of market power has been changing over the period. In 2001, market power of domestic private banks was on average significantly higher than for foreign-owned banks but significantly lower than for state-controlled banks. In 2002, market power of state-controlled banks was not significantly different from that of domestic private and foreign-owned banks. Then, from 2003 to 2007, statecontrolled banks have significantly less market power than foreign-owned and domestic private banks, while both of these latter categories do not have significantly different market power. Thus, the conclusions drawn at first glance, considering only mean market power levels over the period, are misleading. Indeed this quick look shows a decreasing degree of market power for all categories of banks, even though this pattern has not been constant over time.

Second, market power of state-controlled banks was decreased considerably over the period, with a significant drop from $24 \%$ in 2001 to $15.5 \%$ in 2007. This reduction in market power can be explained by the weakening of their competitive advantage in terms of safety. Indeed state-controlled banks used to have an advantage in collecting deposits, as their ownership status has prevented them from going bankrupt. This advantage was particularly important in Russia, where more than 2000 banks have been liquidated or have vanished since the beginning of transition. As a consequence, demand may have been less elastic for state-controlled banks than for other banks, as clients were willing to pay more to have safe deposits. Nevertheless, this competitive advantage has been reduced over time, for two reasons. On the one hand, macroeconomic stability has considerably reduced financial instability, as indicated by the reduction in the average ratio of nonperforming loans to total loans for Russian banks. On the other hand, a deposit insurance scheme was implemented in 2004, leading to the same protection for small depositors in state-controlled and in the other banks as well.

Third, market power has significantly improved for foreign-owned banks, from $15 \%$ in 2001 to $20.1 \%$ in 2007 . Several factors may explain this evolution. On the one 
hand, banking markets are characterized by switching costs, which prevent new competitors to be as competitive as incumbents in attracting customers (Kim, Kliger and Vale, 2001). Therefore, following their entry, foreign-owned banks had incentives to charge lower prices than other banks. However, after attracting customers, foreign-owned banks may have been gradually raising their prices, to become standard banks, which is confirmed by the fact that their market power is not significantly different from the other (domestic) private banks. On the other hand, the increase in market power of foreignowned banks may also derive from the fact that, with the increasing revenue of Russian firms and households, some of these banks have gradually evolved towards an upmarket niche, allowing them to charge higher prices.

Fourth, market power of domestic private banks has decreased slightly but significantly over the period, from $21.5 \%$ in 2001 to $20.6 \%$ in 2007. This moderate evolution may be the result of the competitive pressures resulting from foreign-owned banks. Indeed, at the beginning of the period, foreign-owned banks had lower market power than domestic private banks, which may give the latter an incentive to reduce their margins. In their analysis of the effects of foreign bank entry on a sample of developed and developing countries, Claessens, Demirgüc-Kunt and Huizinga (2001) support this view by concluding that increased presence of foreign banks is associated with a reduction in domestic banks' margins. Available empirical evidence for Russia (Fungáčová and Poghosyan, 2009) shows that in the 2000s the margins of domestic banks in Russia, both state-controlled and private ones, have indeed been decreasing towards the level of margins in foreign-owned banks.

Thus, our major finding is for the existence of significant differences in market power of banks depending on ownership. These differences are of utmost interest for understanding the main pattern of the evolution of bank competition over the period, but they also inform policy recommendations concerning competition.

Indeed we observe that our finding of decreasing market power over time for Russian banks - which was observed for all Russian banks, whether considered as equal or weighted by market share (i.e. enabling a strong influence of state-controlled banks) is driven by the behavior of state-controlled and domestic private banks, and not at all by the behavior of foreign-owned banks. We cannot conclude that foreign bank entry per se 
promotes competition. However, the competitive pressures exerted by foreign-owned banks may have contributed to the reduction in the market power of domestic banks. Thus, our findings do not contradict the commonly accepted view in the literature that foreign bank presence is associated with greater competition in the banking market (e.g. Claessens and Laeven, 2004). Furthermore, the considerable reduction of market power for state-controlled banks over time, resulting in less market power among all categories of banks, does not argue for their privatization for competitive reasons.

\section{IV.3 Determinants of market power of Russian banks}

We now investigate the determinants of market power for Russian banks. In line with former studies, we perform random-effects regressions of Lerner indices on a set of variables. The results are displayed in Table 5. Four different estimations are done, to check the sensitivity of the results. The first estimation includes all tested determinants as defined above (column 1). This is the benchmark specification. The second estimation excludes the regional variables (Herfindahl Index, Loans to Industrial Production, Investor Risk, Industrial Growth) (column 2). The third replaces two determinants by alternative variables (column 3). Namely, we use the market share of the three largest banks (Market Share of big 3) instead of the Herfindahl index to measure concentration, and the ratio of loan loss provisions to total loans (Loan Loss Provisions) instead of nonperforming loans ratio to measure risk. This specification helps us check whether our results are sensitive to the choice of variables to proxy the determinants. The fourth estimation (column 4) uses lagged values in all determinants. This estimation is helpful, as the tested determinants may influence market power with a lag. We use a lag of 3 months to minimize the reduction in the number of observations.

Herfindahl Index has a significantly positive impact on market power as measured by Lerner index. When this variable is replaced by Market Share of big 3, the result is similar. This is in line with the intuitive hypothesis that a more concentrated banking industry contributes to increasing market power of banks. Nonetheless it differs from the non-significant link found for Western European countries (FMP, 2005; FM, 2007). Moreover, it indicates that consolidation of the Russian banking industry, motivated by scale economies or financial stability, might hamper bank competition. 
The coefficient for Log(Assets) is significant and positive, which suggests a positive impact of size on market power. However, the significantly negative coefficient of $\log (\text { Assets })^{2}$ shows that this relationship is nonlinear. This suggests that increasing size enhances market power up to a certain point beyond which greater size becomes detrimental for market power. In other words, small-sized banks and larger banks should have less market power than medium-sized banks. This finding has several implications. First, the "too big to fail" argument, which could carry a competitive advantage in Russia where bank failures have been common during the last decade, is not sufficient to explain banks' market power, however large they are. Second, it suggests that economies of scale may not be strong enough to motivate increased size. Nevertheless further research would be needed to estimate the economies of scale in the Russian banking industry. Third, larger banks resulting from mergers may not necessarily hamper competition. Comparing our results for Russian banks to former studies, we notice that they are in line with the findings of FMP (2005) on European banks, who also find a positive coefficient for size but negative for squared size. On the other hand, our findings differ from the results in the FM (2007) study for Spanish banks.

The estimated coefficient for Loans to Industrial Production, which is an inverse measure of the elasticity of demand, is significantly positive. This finding accords with our expectations, as a lower ratio means greater elasticity of demand via less dependence on bank financing, and consequently less market power. This validation of the theoretical expectation differs from the findings in former studies, as FM (2007) find a nonsignificant coefficient and FMP (2005) find a coefficient which is significantly either positive or negative.

Nonperforming Loans, which measures risk, has a significantly negative estimated coefficient. Replacing this variable by Loan Loss Provisions, we obtain the same result. This finding can be explained by the reduction of margins caused by loan losses, but also in the Russian context, by the diversion of depositors from banks with greater loan losses. The literature provides evidence of depositor's discipline from Russia (see e.g. Karas, Pyle and Schoors, 2010). It is of interest to observe that the measure used for risk in FMP (2005) and FM (2007), the ratio of loan loss provisions to total loans, is not significant. 
So here again the theoretical expectations seem to be valid for Russia rather than for developed countries.

Ownership dummies are not significant. This accords with the observation in the above subsection that neither foreign-owned nor state-controlled banks consistently outperform or underperform domestic private banks in market power over the period of analysis.

Finally, both variables controlling for the macroeconomic and the institutional environment are significant. The coefficient is positive for Industrial Growth, which is an interesting finding because it shows that economic expansion is not necessarily associated with greater banking competition, as we have seen for the Russian banking market as a whole. The significance of Investor Risk variable supports the view that institutional environment influences the behavior of Russian banks. The positive sign of the coefficient may be explained by the fact that greater investor risk prevents new competitors from entering the market.

Thus, the analysis of the determinants of market power for Russian banks has helped us identify the factors which influence bank competition. The fact that our main results have not changed in alternative specifications supports their robustness. In a nutshell, we observe that procompetitive policies in Russia do not include the prohibition of mergers, the relaxed entry of foreign banks or the privatization. Indeed neither large size nor domestic or state ownership are associated with greater market power.

\section{Conclusion}

This paper analyses bank competition in Russia during the period 2001-2007. Our findings can be summarized as follows. First, bank competition only slightly improved between 2001 and 2007. Nevertheless, the level of bank competition is very similar to that observed in the developed countries. Russian banking industry does not seem to suffer from excessive market power of banks. Second, no category of banks among domestic private banks, state-controlled banks, and foreign-owned banks, has been persistently more or less competitive than the others. We observe enhanced market power

for foreign-owned banks and reduced market power for state-controlled banks over the 
period, leading to the finding that the most competitive banks were foreign-owned banks at the beginning of the period, and state-owned banks at the end of the period. Third, our investigation of the determinants of market power identifies the roles of concentration and risk, the absence of impact of ownership, and the nonlinear influence of size, among others things.

In a nutshell, our findings qualify the need for procompetitive policy in the Russian banking industry. Indeed, Russia does not suffer from particularly weak bank competition. Furthermore, the standard policies for promoting competition do not find support here. Namely, the relaxed entry of foreign banks and the privatization of stateowned banks would not likely lead to greater competition. Moreover, the prohibition of mergers to limit bank size may also not favour competition, as the relationship between size and market power is an inverse U-curve.

This conclusion should be related to the finding from Fungáčová and Weill (2009) that greater bank competition enhances the occurrence of bank failures. Indeed, when considering together this possible danger of enhancing bank competition in a country plagued by financial instability and our findings on the fairly normal level of bank competition in Russia and the difficulties of designing a procompetitive policy, one can reasonably wonder whether bank competition should be promoted in this country. Nevertheless, this study is only the first one to investigate bank competition in Russia, and further analysis is needed to confirm our conclusions. 


\section{References}

1. Berger, Allen, and Robert DeYoung, 1997. "Problem Loans and Cost Efficiency in Commercial Banks," Journal of Banking and Finance 21, 849-870.

2. Berger, Allen, Leora Klapper and Rima Turk-Ariss, 2009. "Bank Competition and Financial Stability," Journal of Financial Services Research 35, 2, 99-118.

3. Berglöf, Eric, and Alexander Lehmann, 2008. "Sustaining Russia’s Growth: The Role of Financial Reform," Journal of Comparative Economics 37, 2, 198-206.

4. Berkowitz, Daniel, and David DeJong, 2010. "Growth in Post-Soviet Russia: A Tale of Two Transitions," Journal of Economic Behavior and Organization (forthcoming).

5. Carbo-Valverde, Santiago, David Humphrey, Joaquin Maudos and Philip Molyneux, 2009. "Cross-Country Comparisons of Competition and Pricing Power in European Banking," Journal of International Money and Finance 28, 115-134.

6. Carbo-Valverde, Santiago, Francisco Rodriguez-Fernandez and Gregory Udell, 2009. "Bank Market Power and SME Financing Constraints," Review of Finance 13, 2, 309-340.

7. Cetorelli, Nicola, and Michele Gambera, 2001. "Banking Market Structure, Financial Dependence and Growth: International Evidence from Industry Data". Journal of Finance 56, 617-648.

8. Claessens, Stijn, Asli Demirgüc-Kunt and Harry Huizinga, 2001. "How Does Foreign Entry Affect Domestic Banking Markets?," Journal of Banking and Finance 25, 891-911.

9. Claessens, Stijn, and Luc Laeven, 2004. "What Drives Bank Competition? Some International Evidence," Journal of Money, Credit and Banking 36, 3, 563-583.

10. Claessens, Stijn, and Luc Laeven, 2005. "Financial Dependence, Banking Sector Competition and Economic Growth," Journal of the European Economic Association 3, 1, 179-207.

11. EBRD, 2006. Transition Report 2006: Finance in Transition, European Bank for Reconstruction and Development, London.

12. Fernandez de Guevara, Juan and Joaquin Maudos, 2007. "Explanatory Factors of Market Power in the Banking System," The Manchester School 75, 3, 275-297.

13. Fernandez de Guevara, Juan, Joaquin Maudos and Francisco Perez, 2005. "Market Power in European Banking Sectors," Journal of Financial Services Research 27, 2, 109-137.

14. Fungáčová, Zuzana and Tigran Poghosyan, 2009. “Determinants of Bank Interest Margins in Russia: Does Bank Ownership Matter?” BOFIT Discussion Paper No.22/09, Bank of Finland.

15. Fungáčová, Zuzana and Laurent Weill, 2009. “How Market Power Influences Bank Failures: Evidence from Russia,” BOFIT Discussion Paper No.12/09, Bank of Finland.

16. Karas, Alexei, William Pyle and Koen Schoors, 2010. "Sophisticated Discipline in a Nascent Deposit Market: Evidence from Post-Communist Russia," Oxford Economic Papers 62, 1, 36-61. 
17. Karas, Alexei, Koen Schoors and Laurent Weill, 2010. "Are Private Banks More Efficient than Public Banks? Evidence from Russia,” Economics of Transition 18, 1, 209-244.

18. Kim, Moshe, Doron Kliger and Bent Vale, 2001. "Estimating Switching Costs: The Case of Banking," Journal of Financial Intermediation 12, 1, 25-56.

19. OECD, 2009, OECD Economics Surveys: Russian Federation, Paris.

20. Solis, Liliana, and Joaquin Maudos, 2008. "The Social Costs of Bank Market Power: Evidence from Mexico," Journal of Comparative Economics 36, 3, 467488.

21. Vernikov, Andrei, 2007. "Russia’s Banking Sector Transition: Where to?” BOFIT Discussion Paper No. 5/07, Bank of Finland.

22. Vernikov, Andrei, 2009. "Russian Banking: The State Makes a Comeback?" BOFIT Discussion Paper No.24/09, Bank of Finland.

23. Weill, Laurent, 2008. "How Corruption Affects Bank Lending in Russia," BOFIT Discussion Paper No.18/08, Bank of Finland. 


\section{Table 1}

Main indicators of banking system development in Russia, 2000-2008

\begin{tabular}{lccccc}
\hline & 2000 & 2002 & 2004 & 2006 & 2008 \\
\hline Domestic credit to private sector/ GDP & 12 & 17 & 23 & 30 & 40 \\
Bank assets / GDP & 32 & 38 & 43 & 52 & 67 \\
Number of registered banks & 1311 & 1329 & 1299 & 1189 & 1108 \\
Asset share of foreign-owned banks & 9.5 & 8 & 8 & 12 & 19 \\
\hline
\end{tabular}

Source: CBR, EBRD for asset share of foreign-owned banks

Note: End of period data

Table 2

Descriptive statistics

\begin{tabular}{lccc}
\hline & Mean & Median & St. deviation \\
\hline Lerner index & 0.214 & 0.209 & 0.115 \\
Logarithm of assets & 6.355 & 6.320 & 1.808 \\
Nonperforming loans & 0.019 & 0.005 & 0.045 \\
Herfindahl index & 0.155 & 0.122 & 0.159 \\
Loans to industrial production & 4.907 & 2.270 & 6.093 \\
Industrial growth & 0.232 & 0.215 & 0.144 \\
Investor risk & 23.755 & 15 & 22.998 \\
\hline
\end{tabular}


Table 3

Yearly Lerner indexes

\begin{tabular}{lccccc}
\hline Year & No. of obs. & Mean & Median & St. deviation & $\begin{array}{c}\text { Mean weighted } \\
\text { by size }\end{array}$ \\
\hline 2001 & 3985 & 0.215 & 0.212 & 0.124 & 0.148 \\
2002 & 3941 & 0.218 & 0.212 & 0.120 & 0.156 \\
2003 & 4279 & 0.220 & 0.217 & 0.119 & 0.145 \\
2004 & 4294 & 0.217 & 0.211 & 0.114 & 0.136 \\
2005 & 4156 & 0.211 & 0.205 & 0.105 & 0.150 \\
2006 & 2716 & 0.201 & 0.197 & 0.102 & 0.110 \\
2007 & 855 & 0.204 & 0.201 & 0.103 & 0.103 \\
\hline Total & 24226 & 0.214 & 0.209 & 0.115 & 0.135 \\
\hline
\end{tabular}

Table 4

Lerner indices by ownership

\begin{tabular}{cccccccccccccc}
\hline \multicolumn{1}{c}{ STATE-CONTROLLED } & \multicolumn{3}{c}{ FOREIGN MAJORITY } & \multicolumn{3}{c}{ PRIVATE } \\
\hline Year & Obs. & Mean & Median & St.dev. & Obs. & Mean & Median & St.dev. & Obs. & Mean & Median & St.dev. \\
\hline 2001 & 109 & 0.240 & 0.242 & 0.132 & 99 & 0.149 & 0.173 & 0.162 & 3777 & 0.216 & 0.212 & 0.122 \\
2002 & 107 & 0.209 & 0.202 & 0.111 & 104 & 0.195 & 0.192 & 0.134 & 3730 & 0.219 & 0.212 & 0.120 \\
2003 & 117 & 0.201 & 0.200 & 0.107 & 110 & 0.237 & 0.225 & 0.148 & 4052 & 0.220 & 0.218 & 0.118 \\
2004 & 122 & 0.176 & 0.172 & 0.110 & 112 & 0.211 & 0.220 & 0.158 & 4060 & 0.218 & 0.212 & 0.112 \\
2005 & 123 & 0.178 & 0.171 & 0.098 & 127 & 0.222 & 0.213 & 0.133 & 3906 & 0.212 & 0.206 & 0.104 \\
2006 & 101 & 0.160 & 0.158 & 0.107 & 109 & 0.218 & 0.204 & 0.127 & 2506 & 0.202 & 0.198 & 0.100 \\
2007 & 28 & 0.155 & 0.161 & 0.090 & 38 & 0.201 & 0.203 & 0.115 & 789 & 0.206 & 0.202 & 0.103 \\
\hline Total & 707 & 0.192 & 0.188 & 0.113 & 699 & 0.206 & 0.206 & 0.144 & 22820 & 0.215 & 0.210 & 0.114 \\
\hline
\end{tabular}




\section{Table 5 \\ Determinants of market power}

Random effect estimations where the dependent variable is Lerner index. Standard errors appear in parentheses below estimated coefficients. $*, * *, * * *$ denote an estimate significantly different from 0 at the $10 \%, 5 \%$ or $1 \%$ level. Seasonal and yearly dummy variables and constant included but not reported.

\begin{tabular}{|c|c|c|c|c|}
\hline & $\begin{array}{l}\text { Benchmark } \\
\text { estimation }\end{array}$ & $\begin{array}{c}\text { Without regional } \\
\text { variables }\end{array}$ & $\begin{array}{c}\text { Alternative } \\
\text { variables }\end{array}$ & $\begin{array}{l}\text { Lagged } \\
\text { values }\end{array}$ \\
\hline Log (Assets) & $\begin{array}{c}0.022 * * * \\
(0.003)\end{array}$ & $\begin{array}{c}0.020 * * * \\
(0.003)\end{array}$ & $\begin{array}{c}0.023 * * * \\
(0.003)\end{array}$ & $\begin{array}{c}0.012 * * * \\
(0.003)\end{array}$ \\
\hline Log (Assets) ${ }^{2}$ & $\begin{array}{l}-0.002 * * * \\
(0.0002)\end{array}$ & $\begin{array}{l}-0.002^{* * *} \\
(0.0002)\end{array}$ & $\begin{array}{l}-0.002^{* * *} \\
(0.0002)\end{array}$ & $\begin{array}{l}-0.002 * * * \\
(0.0002)\end{array}$ \\
\hline Nonperforming loans & $\begin{array}{l}-0.135^{* * *} \\
(0.017)\end{array}$ & $\begin{array}{l}-0.131^{* * *} \\
(0.017)\end{array}$ & & $\begin{array}{c}-0.202 * * * \\
(0.021)\end{array}$ \\
\hline Loan loss provisions & & & $\begin{array}{c}-0.037 * * * \\
(0.012)\end{array}$ & \\
\hline State ownership & $\begin{array}{l}-0.003 \\
(0.012)\end{array}$ & $\begin{array}{l}1 . E-05 \\
(0.012)\end{array}$ & $\begin{array}{l}-0.002 \\
(0.012)\end{array}$ & $\begin{array}{l}1 . \mathrm{E}-05 \\
(0.012)\end{array}$ \\
\hline Foreign ownership & $\begin{array}{l}-0.002 \\
(0.007)\end{array}$ & $\begin{array}{l}-0.003 \\
(0.007)\end{array}$ & $\begin{array}{l}-0.003 \\
(0.007)\end{array}$ & $\begin{array}{c}0.009 \\
(0.008)\end{array}$ \\
\hline Herfindahl index & $\begin{array}{c}0.029 * * * \\
(0.009)\end{array}$ & & & $\begin{array}{c}0.024^{* * *} \\
(0.010)\end{array}$ \\
\hline Market share of big 3 & & & $\begin{array}{c}0.021^{* * * *} \\
(0.006)\end{array}$ & \\
\hline $\begin{array}{l}\text { Loans to industrial } \\
\text { production }\end{array}$ & $\begin{array}{l}0.001^{* * * *} \\
(0.0002)\end{array}$ & & $\begin{array}{l}0.001^{* * * *} \\
(0.0002)\end{array}$ & $\begin{array}{l}0.001 * * * \\
(0.0002)\end{array}$ \\
\hline Industrial growth & $\begin{array}{l}0.011^{*} \\
(0.006)\end{array}$ & & $\begin{array}{l}0.011^{*} \\
(0.006)\end{array}$ & $\begin{array}{c}0.003 \\
(0.006)\end{array}$ \\
\hline Investor risk & $\begin{array}{c}0.0003^{* * *} \\
(0.0001) \\
\end{array}$ & & & $\begin{array}{c}0.0002 * * * \\
(0.0001) \\
\end{array}$ \\
\hline $\mathrm{R}^{2}$ & 0.05 & 0.04 & 0.04 & 0.06 \\
\hline $\mathrm{N}$ & 24226 & 24226 & 24226 & 21584 \\
\hline Number of banks & 1312 & 1312 & 1312 & 1284 \\
\hline
\end{tabular}




\title{
Working Papers
}

\section{Laboratoire de Recherche en Gestion \& Economie}

\author{
D.R. $n^{\circ} 1$ "Bertrand Oligopoly with decreasing returns to scale", J. Thépot, décembre 1993 \\ D.R. $n^{\circ} 2$ "Sur quelques méthodes d'estimation directe de la structure par terme des taux d'intérêt", P. Roger - N. \\ Rossiensky, janvier 1994 \\ D.R. $\mathrm{n}^{\circ} 3 \quad$ "Towards a Monopoly Theory in a Managerial Perspective", J. Thépot, mai 1993 \\ D.R. $n^{\circ} 4 \quad$ "Bounded Rationality in Microeconomics", J. Thépot, mai 1993 \\ D.R. $n^{\circ} 5 \quad$ "Apprentissage Théorique et Expérience Professionnelle", J. Thépot, décembre 1993 \\ D.R. $n^{\circ} 6 \quad$ "Strategic Consumers in a Duable-Goods Monopoly", J. Thépot, avril 1994 \\ D.R. $n^{\circ} 7 \quad$ "Vendre ou louer; un apport de la théorie des jeux", J. Thépot, avril 1994 \\ D.R. $\mathrm{n}^{\circ} 8$ \\ D.R. $n^{\circ} 9$ \\ D.R. $\mathrm{n}^{\circ} 10$ \\ D.R. $\mathrm{n}^{\circ} 11$ \\ D.R. $\mathrm{n}^{\circ} 12$ \\ D.R. $\mathrm{n}^{\circ} 13$ \\ D.R. $\mathrm{n}^{\circ} 14$ \\ D.R. $\mathrm{n}^{\circ} 15$ \\ D.R. $\mathrm{n}^{\circ} 16$ \\ D.R. $\mathrm{n}^{\circ} 17$ \\ D.R. $\mathrm{n}^{\circ} 18$ \\ D.R. $\mathrm{n}^{\circ} 19$ \\ "Evaluation of Lot-Sizing Techniques : A robustess and Cost Effectiveness Analysis", J. Jeunet, mars 1996 \\ D.R. $\mathrm{n}^{\circ} 20$ \\ "Entry accommodation with idle capacity", J. Thépot, septembre 1996 \\ "Stabilité d'un diagnostic concurrentiel fondé sur une approche markovienne du comportement de rachat \\ du consommateur", N. Schall, octobre 1995 \\ "A direct proof of the coase conjecture", J. Thépot, octobre 1995 \\ "Invitation à la stratégie", J. Thépot, décembre 1995 \\ "Charity and economic efficiency", J. Thépot, mai 1996 \\ "Pricing anomalies in financial markets and non linear pricing rules", P. Roger, mars 1996 \\ "Non linéarité des coûts de l'assureur, comportement de prudence de l'assuré et contrats optimaux", S. \\ Spaeter, avril 1996 \\ "La valeur ajoutée d'un partage de risque et l'optimum de Pareto : une note", L. Eeckhoudt - P. Roger, juin \\ 1996
}


D.R. $\mathrm{n}^{\circ} 21$ "Différences culturelles et satisfaction des vendeurs : Une comparaison internationale", E. VauquoisMathevet - J.Cl. Usunier, novembre 1996

D.R. n²2 "Evaluation des obligations convertibles et options d'échange", Schmitt - F. Home, décembre 1996

D.R $\mathrm{n}^{\circ} 23 \quad$ "Réduction d'un programme d'optimisation globale des coûts et diminution du temps de calcul, J. Jeunet, décembre 1996

D.R. $\mathrm{n}^{\circ} 24$ "Incertitude, vérifiabilité et observabilité : Une relecture de la théorie de l'agence", J. Thépot, janvier 1997

D.R. $\mathrm{n}^{\circ} 25 \quad$ "Financement par augmentation de capital avec asymétrie d'information : l'apport du paiement du dividende en actions", C. Marie-Jeanne, février 1997

D.R. n²6 "Paiement du dividende en actions et théorie du signal", C. Marie-Jeanne, février 1997

D.R. ${ }^{\circ} 27 \quad$ "Risk aversion and the bid-ask spread", L. Eeckhoudt - P. Roger, avril 1997

D.R. $\mathrm{n}^{\circ} 28$ "De l'utilité de la contrainte d'assurance dans les modèles à un risque et à deux risques", S. Spaeter, septembre 1997

D.R. ${ }^{\circ} 29$ "Robustness and cost-effectiveness of lot-sizing techniques under revised demand forecasts", J. Jeunet, juillet 1997

D.R. $\mathrm{n}^{\circ} 30 \quad$ "Efficience du marché et comparaison de produits à l'aide des méthodes d'enveloppe (Data envelopment analysis)", S. Chabi, septembre 1997

D.R. n 31 "Qualités de la main-d'œuvre et subventions à l'emploi : Approche microéconomique", J. Calaza - P. Roger, février 1998

D.R $\mathrm{n}^{\circ} 32$ "Probabilité de défaut et spread de taux : Etude empirique du marché français", M. Merli - P. Roger, février 1998

D.R. $n^{\circ} 33 \quad$ "Confiance et Performance : La thèse de Fukuyama", J.Cl. Usunier - P. Roger, avril 1998

D.R. $n^{\circ} 34 \quad$ "Measuring the performance of lot-sizing techniques in uncertain environments", J. Jeunet - N. Jonard, janvier 1998

D.R. $\mathrm{n}^{\circ} 35$ "Mobilité et décison de consommation : premiers résultas dans un cadre monopolistique", Ph. Lapp, octobre 1998

D.R. $n^{\circ} 36 \quad$ "Impact du paiement du dividende en actions sur le transfert de richesse et la dilution du bénéfice par action", C. Marie-Jeanne, octobre 1998

D.R. $\mathrm{n}^{\circ} 37$ "Maximum resale-price-maintenance as Nash condition", J. Thépot, novembre 1998

D.R. $\mathrm{n}^{\circ} 38 \quad$ "Properties of bid and ask prices in the rank dependent expected utility model", P. Roger, décembre 1998

D.R. n 39 "Sur la structure par termes des spreads de défaut des obligations ", Maxime Merli / Patrick Roger, septembre 1998

D.R. $n^{\circ} 40 \quad$ "Le risque de défaut des obligations : un modèle de défaut temporaire de l'émetteur", Maxime Merli, octobre 1998

D.R. n $41 \quad$ "The Economics of Doping in Sports", Nicolas Eber / Jacques Thépot, février 1999

D.R. $n^{\circ} 42 \quad$ "Solving large unconstrained multilevel lot-sizing problems using a hybrid genetic algorithm", Jully Jeunet, mars 1999 
D.R. $n^{\circ} 44$

D.R. $n^{\circ} 45$

D.R. $n^{\circ} 46$

D.R. $n^{\circ} 47$

D.R. $n^{\circ} 48$

D.R. $n^{\circ} 49$

D.R. $n^{\circ} 50$

D.R. $n^{\circ} 51$

D.R. $n^{\circ} 52$

D.R. $n^{\circ} 53$

D.R. $n^{\circ} 54$

D.R. $n^{\circ} 55$

D.R. $n^{\circ} 56$

D.R. $n^{\circ} 57$

D.R. $n^{\circ} 58$

D.R. $n^{\circ} 59$

D.R. $n^{\circ} 60$

D.R. $n^{\circ} 61$

D.R. $n^{\circ} 62$

D.R. $n^{\circ} 63$

D.R. $n^{\circ} 64$

D.R. $n^{\circ} 65$

D.R. $n^{\circ} 66$

D.R. $n^{\circ} 67$

"Doping in Sport and Competition Design", Nicolas Eber / Jacques Thépot, septembre 1999

"Interactions dans les canaux de distribution", Jacques Thépot, novembre 1999

"What sort of balanced scorecard for hospital", Thierry Nobre, novembre 1999

"Le contrôle de gestion dans les PME", Thierry Nobre, mars 2000

"Stock timing using genetic algorithms", Jerzy Korczak - Patrick Roger, avril 2000

"On the long run risk in stocks : A west-side story", Patrick Roger, mai 2000

"Estimation des coûts de transaction sur un marché gouverné par les ordres : Le cas des composantes du CAC40", Laurent Deville, avril 2001

"Sur une mesure d'efficience relative dans la théorie du portefeuille de Markowitz", Patrick Roger / Maxime Merli, septembre 2001

"Impact de l'introduction du tracker Master Share CAC 40 sur la relation de parité call-put", Laurent Deville, mars 2002

"Market-making, inventories and martingale pricing", Patrick Roger / Christian At / Laurent Flochel, mai 2002

"Tarification au coût complet en concurrence imparfaite", Jean-Luc Netzer / Jacques Thépot, juillet 2002

"Is time-diversification efficient for a loss averse investor ?", Patrick Roger, janvier 2003

“Dégradations de notations du leader et effets de contagion", Maxime Merli / Alain Schatt, avril 2003

"Subjective evaluation, ambiguity and relational contracts", Brigitte Godbillon, juillet 2003

"A View of the European Union as an Evolving Country Portfolio", Pierre-Guillaume Méon / Laurent Weill, juillet 2003

“Can Mergers in Europe Help Banks Hedge Against Macroeconomic Risk ?”, Pierre-Guillaume Méon / Laurent Weill, septembre 2003

"Monetary policy in the presence of asymmetric wage indexation", Giuseppe Diana / Pierre-Guillaume Méon, juillet 2003

"Concurrence bancaire et taille des conventions de services", Corentine Le Roy, novembre 2003

"Le petit monde du CAC 40", Sylvie Chabi / Jérôme Maati

"Are Athletes Different? An Experimental Study Based on the Ultimatum Game", Nicolas Eber / Marc Willinger

"Le rôle de l'environnement réglementaire, légal et institutionnel dans la défaillance des banques : Le cas des pays émergents", Christophe Godlewski, janvier 2004

"Etude de la cohérence des ratings de banques avec la probabilité de défaillance bancaire dans les pays émergents", Christophe Godlewski, Mars 2004

“Le comportement des étudiants sur le marché du téléphone mobile : Inertie, captivité ou fidélité ?", Corentine Le Roy, Mai 2004

"Insurance and Financial Hedging of Oil Pollution Risks", André Schmitt / Sandrine Spaeter, September, 2004 
D.R. $\mathrm{n}^{\circ} 68$ "On the Backwardness in Macroeconomic Performance of European Socialist Economies", Laurent Weill, September, 2004

D.R. $\mathrm{n}^{\circ} 69$ "Majority voting with stochastic preferences : The whims of a committee are smaller than the whims of its members", Pierre-Guillaume Méon, September, 2004

D.R. $\mathrm{n}^{\circ} 70 \quad$ "Modélisation de la prévision de défaillance de la banque : Une application aux banques des pays émergents", Christophe J. Godlewski, octobre 2004

D.R. $\mathrm{n}^{\circ} 71 \quad$ "Can bankruptcy law discriminate between heterogeneous firms when information is incomplete ? The case of legal sanctions", Régis Blazy, october 2004

D.R. $\mathrm{n}^{\circ} 72$ "La performance économique et financière des jeunes entreprises", Régis Blazy/Bertrand Chopard, octobre 2004

D.R. $\mathrm{n}^{\circ} 73 \quad$ "Ex Post Efficiency of bankruptcy procedures: A general normative framework", Régis Blazy / Bertrand Chopard, novembre 2004

D.R. $n^{\circ} 74 \quad$ "Full cost pricing and organizational structure", Jacques Thépot, décembre 2004

D.R. $\mathrm{n}^{\circ} 75 \quad$ "Prices as strategic substitutes in the Hotelling duopoly", Jacques Thépot, décembre 2004

D.R. $n^{\circ} 76$ "Réflexions sur l'extension récente de la statistique de prix et de production à la santé et à l'enseignement", Damien Broussolle, mars 2005

D. R. n $77 \quad$ "Gestion du risque de crédit dans la banque : Information hard, information soft et manipulation", Brigitte Godbillon-Camus / Christophe J. Godlewski

D.R. $\mathrm{n}^{\circ} 78$

"Which Optimal Design For LLDAs", Marie Pfiffelmann

D.R. $\mathrm{n}^{\circ} 79$

"Jensen and Meckling 30 years after : A game theoretic view", Jacques Thépot

D.R. $\mathrm{n}^{\circ} 80$

“Organisation artistique et dépendance à l'égard des ressources”, Odile Paulus, novembre 2006

D.R. $\mathrm{n}^{\circ} 81$

D.R. $\mathrm{n}^{\circ} 82$

"Does collateral help mitigate adverse selection ? A cross-country analysis", Laurent Weill -Christophe J. Godlewski, novembre 2006

D.R. $\mathrm{n}^{\circ} 83$ "The peace of work agreement : The emergence and enforcement of a swiss labour market institution", D. Broussolle, janvier 2006.

D.R. $n^{\circ} 84 \quad$ "The new approach to international trade in services in view of services specificities : Economic and regulation issues", D. Broussolle, septembre 2006.

D.R. $n^{\circ} 85$ "Does the consciousness of the disposition effect increase the equity premium" ?, P. Roger, juin 2007

D.R. $n^{\circ} 86 \quad$ "Les déterminants de la décision de syndication bancaire en France", Ch. J. Godlewski

D.R. n 87 "Syndicated loans in emerging markets", Ch. J. Godlewski / L. Weill, mars 2007

D.R. $n^{\circ} 88$ "Hawks and loves in segmented markets : A formal approach to competitive aggressiveness", Claude d’Aspremont / R. Dos Santos Ferreira / J. Thépot, mai 2007

D.R. n 89 "On the optimality of the full cost pricing", J. Thépot, février 2007

D.R. $\mathrm{n}^{\circ} 90 \quad$ "SME's main bank choice and organizational structure : Evidence from France", H. El Hajj Chehade / L. Vigneron, octobre 2007 
D.R n` 91 “How to solve St Petersburg Paradox in Rank-Dependent Models" ?, M. Pfiffelmann, octobre 2007

D.R. $n^{\circ} 92 \quad$ "Full market opening in the postal services facing the social and territorial cohesion goal in France", D. Broussolle, novembre 2007

D.R. $n^{\circ}$ 2008-01 A behavioural Approach to financial puzzles, M.H. Broihanne, M. Merli, P. Roger, janvier 2008

D.R. $n^{\circ} 2008-02$

What drives the arrangement timetable of bank loan syndication ?, Ch. J. Godlewski, février 2008

D.R. $\mathrm{n}^{\circ} 2008-03$ Financial intermediation and macroeconomic efficiency, Y. Kuhry, L. Weill, février 2008

D.R. $\mathrm{n}^{\circ} 2008-04$ The effects of concentration on competition and efficiency : Some evidence from the french audit market, G. Broye, L. Weill, février 2008

D.R. $\mathrm{n}^{\circ} 2008-05$

Does financial intermediation matter for macroeconomic efficiency?, P.G. Méon, L. Weill, février 2008

D.R. $\mathrm{n}^{\circ} 2008-06$ Is corruption an efficient grease ?, P.G. Méon, L. Weill, février 2008

D.R. $n^{\circ} 2008-07$ Convergence in banking efficiency across european countries, L. Weill, février 2008

D.R. $\mathrm{n}^{\circ} 2008-08$ Banking environment, agency costs, and loan syndication : A cross-country analysis, Ch. J. Godlewski, mars 2008

D.R. $\mathrm{n}^{\circ} 2008-09$ Are French individual investors reluctant to realize their losses ?, Sh. Boolell-Gunesh / M.H. Broihanne / M. Merli, avril 2008

D.R. $\mathrm{n}^{\circ} 2008-10$ Collateral and adverse selection in transition countries, Ch. J. Godlewski / L. Weill, avril 2008

D.R. $n^{\circ} 2008-11$ How many banks does it take to lend ? Empirical evidence from Europe, Ch. J. Godlewski, avril 2008.

D.R. $\mathrm{n}^{\circ} 2008-12$ Un portrait de l'investisseur individuel français, Sh. Boolell-Gunesh, avril 2008

D.R. $\mathrm{n}^{\circ} 2008-13$ La déclaration de mission, une revue de la littérature, Odile Paulus, juin 2008

D.R. $\mathrm{n}^{\circ} 2008-14$ Performance et risque des entreprises appartenant à des groupes de PME, Anaïs Hamelin, juin 2008

D.R. $\mathrm{n}^{\circ} 2008-15$ Are private banks more efficient than public banks ? Evidence from Russia, Alexei Karas / Koen Schoors / Laurent Weill, septembre 2008

D.R. $\mathrm{n}^{\circ} 2008-16$ Capital protected notes for loss averse investors : A counterintuitive result, Patrick Roger, septembre 2008

D.R. $\mathrm{n}^{\circ} 2008-17$ Mixed risk aversion and preference for risk disaggregation, Patrick Roger, octobre 2008

D.R. $\mathrm{n}^{\circ} 2008-18$ Que peut-on attendre de la directive services ?, Damien Broussolle, octobre 2008

D.R. $\mathrm{n}^{\circ} 2008-19$ Bank competition and collateral: Theory and Evidence, Christa Hainz / Laurent Weill / Christophe J. Godlewski, octobre 2008

D.R. $\mathrm{n}^{\circ} 2008-20$ Duration of syndication process and syndicate organization, Ch. J. Godlewski, novembre 2008

D.R. $\mathrm{n}^{\circ} 2008-21$ How corruption affects bank lending in Russia, L. Weill, novembre 2008

D.R. $\mathrm{n}^{\circ} 2008-22$

On several economic consequences of the full market opening in the postal service in the European Union, D. Broussolle, novembre 2008. 
D.R. $\mathrm{n}^{\circ} 2009-01$

D.R. $\mathrm{n}^{\circ} 2009-02$

D.R. $n^{\circ} 2009-03$

D.R. $n^{\circ} 2009-04$

D.R. $n^{\circ} 2009-05$

D.R. $n^{\circ} 2009-06$

D.R. $n^{\circ} 2009-07$

D.R. $n^{\circ} 2009-08$

D.R. $n^{\circ} 2009-09$

D.R. $n^{\circ} 2009-10$

D.R. $n^{\circ} 2009-11$

D.R. $n^{\circ} 2009-12$

D.R. $n^{\circ} 2009-13$

D.R. $n^{\circ} 2009-14$

D.R. n 2010-01

D.R. $\mathrm{n}^{\circ}$ 2010-02

D.R. $n^{\circ} 2010-03$

D.R. $n^{\circ} 2010-04$

D.R. $n^{\circ} 2010-05$

D.R. $\mathrm{n}^{\circ} 2010-06$

D.R. $n^{\circ} 2010-07$

D.R. $n^{\circ} 2010-08$

D.R. ${ }^{\circ} 2010-09$
Asymmetric Information and Loan Spreads in Russia: Evidence from Syndicated Loans, Z. Fungacova, C.J. Godlewski, L. Weill

Do Islamic Banks Have Greater Market Power ?, L. Weill

CEO Compensation: Too Much is not Enough!, N. Couderc \& L. Weill

La cannibalisation des produits à prix aléatoires : L'Euromillions a-t-il tué le loto français?, P. Roger \& S. Chabi

The demand for Euromillions lottery tickets: An international comparison, P. Roger

Concentration in corporate bank loans What do we learn from European comparisons?, C.J. Godlewski \& Y. Ziane

Le mariage efficace de l'épargne et du jeu : une approche historique, M. Pfiffelmann

Testing alternative theories of financial decision making: an experimental study with lottery bonds, P. Roger

Does Corruption Hamper Bank Lending? Macro and Micro Evidence, L. Weill

La Théorie Comportementale du Portefeuille et l'Equilibre du Marché, O. Bourachnikova

Déformation des Probabilités Objectives et la Théorie Comportementale du Portefeuille, O. Bourachnikova

La Théorie Comportementale du Portefeuille vs. le modèle moyenne - variance. Étude empirique, O. Bourachnikova

Symmetric vs. Downside Risk: Does It Matter for Portfolio Choice? O. Bourachnikova \& N. Yusupov

Negative Agency Costs, J. Thépot

Does family control of small business lead to under exploitation of their financial growth potential? Evidence of the existence of conservative growth behavior in family controlled French SMEs, A. Hamelin

Better borrowers, fewer banks?, CJ. Godlewski \& F. Lobez \& J.-C. Statnik \& Y. Ziane

Responsabilité sociale de l'entreprise et théorie de l'organisation, J. Thépot

Small business groups enhance performance and promote stability, not expropriation. Evidence from French SMEs, A. Hamelin

Are Islamic Investment Certificates Special? Evidence on the Post-Announcement

Performance of Sukuk Issues, C.J. Godlewski \& R. Turk-Ariss \& L. Weill

Trading activity and Overconfidence: First Evidence from a large European Database, $\mathrm{S}$. Boolell-Gunesh \& M. Merli

Bank lending networks, experience, reputation, and borrowing costs, C.J. Godlewski, B. Sanditov, T. Burger-Helmchen

How Market Power Influences Bank Failures Evidence from Russia, Z. Fungacova, L. Weill Market Power in the Russian Banking Industry, Z. Fungacova, L. Solanko, L. Weill 
